\title{
Different convergence rates of new EU member states: Panel data analysis of the causes
}

\author{
Josip Visković ${ }^{1, *}$, Paško Burnać ${ }^{1}$ and Ivan Ramljak ${ }^{2}$ \\ ${ }^{1}$ Faculty of Economics, Business and Tourism, University of Split \\ Cvite Fiskovića 5, 21000 Split, Croatia \\ E-mail: 〈\{jviskovi,pburnac\}@efst.hr〉 \\ 2 Goolets. Ltd, Slovenia \\ E-mail: 〈ivanramjakrama@gmail.com〉
}

\begin{abstract}
This paper, using panel data analysis, tries to identify factors regarding the different convergence rates of CESEE EU member countries' real income between 2002 and 2018. Stylized convergence facts are identified and the drivers of economic growth based on production function, i.e. the accumulation of labour and capital and total factor productivity (TFP) growth have been analysed. Moreover, paper takes into account other variables that have been recognized as growth determining factors trade openness, FDI, labour market and integration level, as well as TFP determining factors - institutional quality, innovation and human capital. Based on the research results trade openness and gross capital formation have been identified as key factors regarding real income growth of analysed countries. Also, it has been confirmed that growth of CESEE countries is strongly affected by the growth of Eurozone. Finally, the authors' conclusion is that several CESEE countries are facing institutional convergence challenges.
\end{abstract}

Keywords: CESEE countries, convergence rate, economic growth, panel data analysis

Received: September 30, 2020; accepted: December 04, 2020; available online: December 18, 2020

DOI: $10.17535 /$ crorr.2020.0023

\section{Introduction}

Convergence examines whether poor countries or regions tend to grow faster than rich ones or not. It answers are there forces that lead to convergence over time regarding per capita income and product. Based on the theory of neoclassical growth, Barro and Sala-i-Martin [4] have analysed whether 48 contiguous U.S. states converged in the period 1840-1988. The empirical results provided evidence showing the tendency of poor economies to grow faster than rich ones in per capita terms. According to Siljak and Nagy, [24] the European Union has focused on convergence since the Treaty of Rome (1957), which was complemented with establishment of the European Regional Development Fund whose key aim was to develop less developed regions in order to reach the developed ones. Transition countries on their way to European Economic and Monetary Union were obliged to Copenhagen criteria and Maastricht convergence criteria. Even though empirical results show that new EU member countries (EU12) are generally converging to old member states (EU15) the fact is that the pace of convergence is different and has changed over time. Moreover, convergence criteria proved not to be crucial in the pace of convergence rate and therefore research oriented towards factors that determine the successfulness of convergence of new EU member countries towards

${ }^{*}$ Corresponding author.

http://www.hdoi.hr/crorr-journal

(C)2020 Croatian Operational Research Society 
the old member states. Stylized facts regarding crucial factors that determine convergence rate include capital accumulation, foreign direct investments, trade openness, labour market flexibility and total factor productivity. Therefore, the aim of the paper is threefold: to analyse the determinants of the convergence of Central, Eastern and South-Eastern Europe (CESEE) EU member countries, to differentiate those that grow faster and to define determinants that contribute to higher convergence pace.

Economic theory differentiates between two types of beta convergence - absolute (unconditional) and conditional convergence. Absolute convergence states that countries with the same population growth and the same stock of capital and production function will reach the same level of income. On the other hand, conditional convergence states that parameters differ among countries and that those different countries will achieve different levels of income which means they will converge to the average of a certain convergence club. Jelnikar and Murmayer [15] tested and confirmed hypothesis of conditional convergence among EU15 and EU10 group. Moreover, they have also shown that during the period 1995-2007 the EU10 group moved closer to the average per capita income level of EU15. Vojinović, Acharya and Próchniak [28] have analysed sigma (reduction in the dispersion of levels of income across economies) and beta convergences (absolute and conditional) of GDP per capita among ten Central and East European countries in the period 1992-2006. Their results confirmed both types of convergence. Namely, the poorer EU member states grew faster than the richer member states. Kulhánek [17] has shown in his paper that five Central European countries - Czech Republic, Hungary, Poland, the Slovak Republic and Slovenia are well positioned to catch up with the EU15 average, but are converging at a slower rate than EU12 member states.

Dvoroková [11] focused her research on the impact of financial crisis on the real convergence among EU member states. Using a cross-sectional linear regression analysis the author concluded that in the period between 2001 and 2012 beta convergence occurred among EU countries. In their paper, [9] have analysed the speed and patterns of economic convergence in the new EU member states and have concluded that there is growth heterogeneity, i.e. uneven economic convergence within the EU. Their results imply presence of unobserved factors that define the pace of convergence. Findings of Borsi and Metiu [5] suggest that there is no overall income convergence in the EU. Still, they have found convergence clubs based on the geographical properties. In their research, they have paid special attention to institutional changes and macroeconomic adjustment processes. The economic convergence of Central and Eastern European countries was also confirmed in the paper of Colak [7]. However, the convergence process was interrupted by financial crisis [14].

Due to the fact that panel data set has multiple entities (in our case countries), each of which has repeated measurements of particular variables at different time periods, panel data analysis is considered as an adequate method for this type of research. Furthermore, "panel data give more informative data, more variability, less collinearity among the variables, more degrees of freedom and more efficiency" [3].

The rest of the paper is organized as follows. Section 2 provides theoretical and literature review on convergence of new EU member states. Section 3 presents data and methodology. Section 4 presents research results and provides discussion. Finally, the paper closes with concluding remarks in Section 5.

\section{Theoretical and literature review}

Taking into consideration previous research, the question that arises is: Which of the factors that affect the pace of convergence are crucial in the long run? Therefore, this paper will investigate the causes of different degrees of convergence rate. Research will focus on new EU member countries. Determinants that will be analysed are capital accumulation, foreign direct 
investments, trade openness, Eurozone growth, labour market and total factor productivity factors that include innovation, institution quality and human capital.

Based on the model of Solow [29] capital accumulation has been recognized as one of the key factors of economic growth. Spence, [25] besides finding that economies grow faster in the post-war period, has emphasized that in a period of faster convergence countries showed a ratio of investment to GDP above 25\%. Investment was also booming in most transition economies before 2008 and in twelve countries investment rates were above $25 \%$ of GDP. The pre-crisis investment boom was fuelled by strong demand growth and was largely financed by capital inflows. After the crisis, the investment ratio decreased significantly. As for CESEE economies, investments are necessary for rapid accumulation of capital and convergence with advanced EU member states.

The importance of capital inflows for Central and Eastern European (CEE) countries has been emphasized by Damijan, Kostevc and Rojec [8]. Namely, foreign direct investments (FDI) had a positive impact on capital accumulation and enabled the transfer of technology and knowledge, supporting total factor productivity growth. Fidrmuc and Martin [12] have also confirmed positive relation between export and stock of FDI with industrial production and economic growth in CESEE region. Still, investment in CESEE is regarded to be highly procyclical and volatile and mainly oriented to machinery and infrastructure, and less towards $\mathrm{R} \& \mathrm{D}[6]$.

Trade openness has been recognized in many papers with Rodríguez and Rodrik [22] and Rodríguez [21] to point out. A country that is more opened can support higher level of economic growth in the long run, and increased trade flows allow redirection of resources within the sector and specialization between countries thus increasing efficiency and revenue levels. CESEE countries are all characterized with high level of trade openness. Namely, with high level of trade openness, which has increased in almost all CESEE countries since 2000, creating favourable conditions for income convergence. Still, high degree of trade openness may not be enough to attain a sustainable convergence rate, especially if it is not supported by improved competitiveness.

In the last twenty years, only some transition countries have managed to take advantage of the demographic dividend, i.e. to stimulate the potential for economic growth associated with an increase in the share of the working age population in the total population. Although this share increased in some CESEE countries, others such as Baltic countries have recorded negative trends. Accordingly, since 2000 the contribution of labour to economic growth in transition economies when compared to other emerging economies has on average been low. Although the underlying demographic trends were diverse, all transition countries experienced adverse migration trends. Regarding labour market, Atoyan et al. [2] concluded that labour outflows, especially of skilled workers, lowered productivity growth and pushed up wages which resulted in slower growth and slower convergence of income. Moreover, the outflow of labour was particularly large in Southeast Europe, as well in countries that had already joined the EU (about $11 \%$ of the population in 1990) as in non-EU countries (10\%). Still, it was somewhat lower in Baltic and CEE countries (5-6\%). Unfavourable migration trends accelerated after EU accession. Thus, as emigration was mostly related to young and skilled workforce, productivity and income convergence were negatively affected. Moreover, these countries are characterized by ageing population, which may reduce overall productivity.

A number of papers investigating the relationship between economic growth and human capital development have found the two-way relationship with human capital development playing crucial role in defining growth trajectories [29]. Although human capital cannot be directly measured, it can be approximated by variables such as the percentage of the workforce with higher education or the enrolment rate in higher (tertiary) education. Regarding these indicators, most CESEE countries perform relatively well compared to the EU average. In particular, the share of the population with baccalaureus degree in the Baltic States is higher, 
and in CEE countries it is similar to EU average. Moreover, since the year 2000, tertiary education enrolment has increased in all CESEE countries, which indicates the growth of human capital, which might positively affect productivity and economic growth in the future.

The institution quality is often considered to be a crucial determinant for economic growth. Besides it also explains long-term differences between countries considering economic development $[1,23]$ Although institutions are endogenous, which means that they are determined by society and can be a function of the income, institution quality improvement does not occur automatically. Kaufmann and Kraay [16] found a strong positive causal effect ranging from better governance to higher per capita income which emphasizes the importance of good governance.

Finally, innovations are perceived as a key driver of productivity increase, higher level of competitiveness and economic growth. Pece, Simona and Salisteanu [20] have conducted an analysis for CEE countries and confirmed a positive relationship between economic growth and innovation. Maradana et al. [19] examined the long-run relationship between innovation and per capita economic growth in 19 European countries over the period 1989-2014 and have found presence of both unidirectional and bidirectional causality between innovation and per capita economic growth. Although in recent years some CESEE countries have managed to improve innovation level in relation to the EU15, others have lagged and stalled.

\section{Data and methodology}

This paper examines the causes of different convergence rates of 11 CESEE new EU member states: Bulgaria, Croatia, the Czech Republic, Estonia, Hungary, Latvia, Lithuania, Poland, Slovakia, Slovenia and Romania. Variables that represent determinants of convergence are: (i) Gross Capital Formation as capital accumulation; (ii) foreign direct investments (FDI to GDP); (iii) trade openness as ratio of a sum of export and import to GDP; (iv) the ratio of the working age population in total population indicating the labour market characteristics (D1Ages 1664 Total); (v) number of patents in GDP represent innovation; (vi) institution quality is expressed by World Bank Index that encompasses four indicators - regulatory quality, government effectiveness, control of corruption and the rule of law (D1Inst AVG T) and (vii) the level of highly educated individuals expressed as the ratio of enrolled students in tertiary education in total education presents human capital indicator (Tertiary Total).

The annual data are taken from following databases: European Commission (AMECO database), IMF, OECD, Penn World Table v9.1, United Nations, World Economic Forum (GCI), Wiiw (FDI database), World Bank and World Intellectual Property Organisation statistic database. Analysed period encompasses the period between 2002 and 2018 because since 2002 all the CESEE EU member countries have finished transition period and transformed their economies to market economies.

GDP per capita and GDP growth for all countries are presented in Figure 1 and Figure 2. Figure 1 generally shows the growth trend for all countries and it is evident that initial difference among countries has been diminishing. Nevertheless, the rate of convergence varied across

countries and periods. Namely, most convergence occurred before financial crisis (Hungary, Croatia, Romania and Slovenia) while after the financial crisis some countries have been converging more slowly (Bulgaria) and some even faster (Estonia, Lithuania, Latvia and Poland). Figure 2 shows that financial crisis had a negative impact on GDP growth of CESEE countries. However, the effect of crisis was different with Poland being affected significantly less than for example Latvia and Lithuania. Moreover, after financial crisis growth rates differed with Latvia and Lithuania growing faster than for example Croatia and Hungary implying decline in conditional convergence with financial crisis as inflection point. However, convergence seems to be improved in 2014, but from 2016 onwards the situation slightly worsened. 


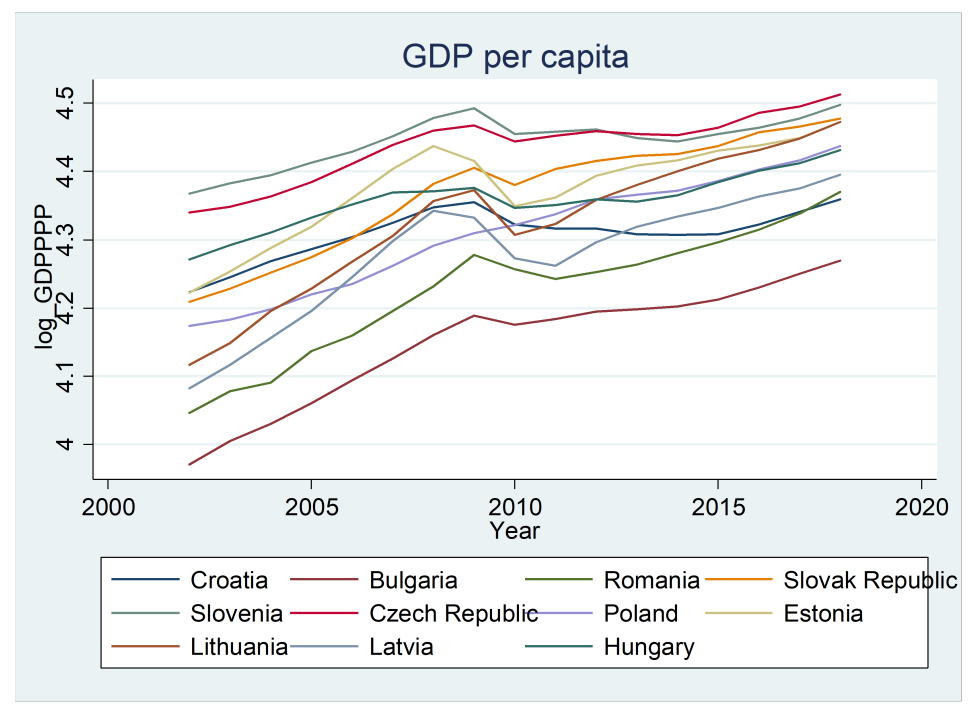

Figure 1: GDP per capita of CESEE countries

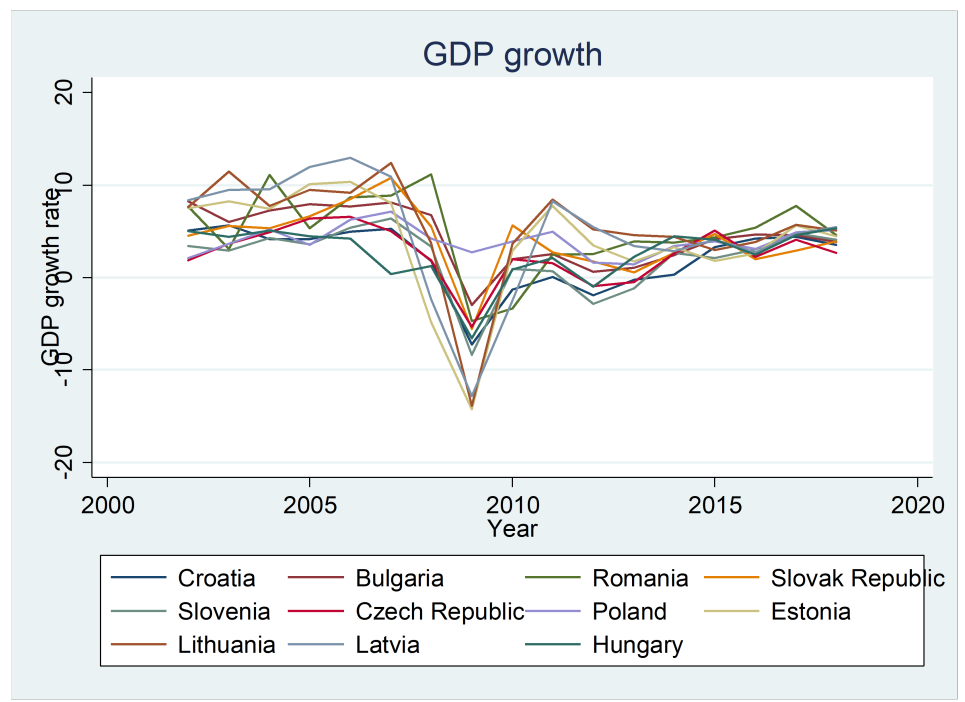

Figure 2: GDP growth of CESEE countries

Following the model proposed by Mankiw et al. [18] we define our theoretical model of conditional convergence adopted to panel data:

$$
\Delta y_{i t}=\alpha+\beta y_{i t-1}+\gamma^{\prime} \Phi_{i t}+\varepsilon_{i t}, \quad i=1,2, \ldots, N \quad t=1,2, \ldots, N,
$$

where $\Delta y_{i t}$ is the annual growth rate of the country $i$ in year $t, y_{i t-1}$ is the lagged variable in the levels and $\Phi_{i t}$ is the vector of control variables as defined above.

According to characteristics of panel data a different estimators were employed. BreuschPagan test (LM test), by testing the variance of the individual effects, shows that random effect model is more suitable than pooled OLS (Table1). However, according to results of Hausman specification test [13], which compares fixed effect model with random effect model, fixed effect 
model proved to be more suitable than random effect model. According to the results of $\mathrm{F}$-test that compares fixed effect model with OLS (pooled) model, fixed effect model again proved to be more suitable. As our panel has an independent variable from the previous period then a dynamic model should be applied, but not a standard dynamic model because the dependent variable is in the first differences (GDP growth) while the lagged variable is in the levels. Still, our model can be estimated by the GMM method under conditions when $T>N$ (17 years, 11 countries) and therefore we also apply LSDVc estimator [28], which is most commonly used in dynamic panel models where it is assumed that individual effects are fixed (dynamic panel + one-way fixed effect). Namely, LSDVc corrects estimation bias. In order to examine the assumption of serial correlation, community-contributed programme called xtserial was performed in Stata [10]. Moreover, in order to solve the problem of autocorrelation, clustered standard errors (CSE), that are generally recommended when analyzing panel data, were applied. Besides, CSE also account for heteroscedasticity. Finally, the Levin-Lin-Chu unit root tests show the stationarity of time series in first differences (due to space limit, results are available on request).

\section{Results and discussion}

Research results of all our models are presented in Table 1. Suitability tests proved that the fixed effect (FE) model is the most suitable, but also other models confirm the effects of independent variables and provide relatively similar results. Moreover, the results of fixed effect model were proved by LSDVc estimator. Namely, GDP growth is significantly negatively related to lagged GDP per capita, which is in line with the $\beta$-convergence hypothesis, i.e. it confirms that countries have been converging in the analysed period. GDP growth in Eurozone has shown to have a strong impact on economic growth in CESEE countries, which implies high level of importance of Eurozone for economic growth of CESEE economies. Also, greater gross capital formation, investments and greater trade openness contributed positively to growth. These results are in line with theoretical assumptions and previous research.

\begin{tabular}{|l|cccc|}
\hline Variable & OLS & FE & RE & LSDVc \\
\hline \hline GR_CC_PPP L1. & & & & $0.2491^{* * *}$ \\
Lagged_log_GDPPP & $-15.0038^{* * *}$ & $-33.7949^{* * *}$ & $-16.2044^{* * *}$ & $-32.6436^{* * *}$ \\
Tertiary Total & $0.0269^{*}$ & -0.0104 & 0.0249 & 0.0022 \\
D1Ages 15 64 Total & 0.6251 & -2.4311 & 0.2587 & -2.3743 \\
D1Patent_Million & -0.0092 & -0.0077 & -0.0108 & 0.0017 \\
GCF_GDP & $0.2365^{* * *}$ & $0.3906^{* * *}$ & $0.2569^{* * *}$ & $0.2213^{* * *}$ \\
FDI_GDP & -0.0388 & -0.0196 & -0.0359 & -0.0278 \\
Trade_GDP & $0.0227^{* * *}$ & $0.0792^{* * *}$ & $0.0254^{* * *}$ & $0.0723^{* *}$ \\
D1Inst AVG T & $7.1047^{* *}$ & 4.0775 & $6.7377^{*}$ & 3.7916 \\
Euro_Growth & $1.4736^{* * *}$ & $1.1643^{* * *}$ & $1.4468^{* * *}$ & $1.2628^{* * *}$ \\
Constant & $56.7064^{* *}$ & $129.6380^{* * *}$ & $61.1647^{* * *}$ & \\
\hline Number of observations & 176 & 176 & 176 & 176 \\
Number of groups & 11 & 11 & 11 & 11 \\
F-test & $7.55^{* * *}$ & $7.55^{* * *}$ & & \\
LM test & $15.87^{* * *}$ & & $15.87^{* * *}$ & \\
Hausman test & & $47.67^{* * *}$ & $47.67^{* * *}$ & \\
Sigma_u & & 2.53206 & 0.29591 & \\
Sigma_e & & 2.11861 & 2.11861 & \\
\hline
\end{tabular}

Table 1: Determinants of the GDP growth in CESEE countries in period 2002-2018 
Other variables, FDI, labour market, human capital, institutions and innovation did not prove to be significant, what is not in line with theoretical assumptions and previous research. This confirms that pattern of economic convergence has changed over time and there is need to scrutinize the causes.

Surprisingly, FDI were not proved as significant. Still, our period covers post crisis period when capital flows to CESEE region dropped and remained low with the largest decline of inward FDI. The decline of inward FDI, besides omitting its positive direct effects on economy, also had a negative catalytic effect on domestic investment. The result was a decline in productivity and slower post-crisis growth, which explains insignificance of FDI in our models.

With regard to labour market, it is important to stress that CESEE countries were characterized by significant emigration of the working age population during the phase of economic growth from 2013 to 2018. This has negatively affected productivity, economic growth and the convergence process in CESEE economies. When last three years are omitted from the analysis our results confirm the positive effect of the labour market variable. Another important aspect is the aging population in CESEE countries. Namely, most CESEE countries with South Korea and Taiwan record the worst indicators of fertility rate. That is something that CESEE countries must take in consideration and take adequate measures in order to improve such indicators.

Human capital proved to be insignificant as well, i.e. it did not contribute to convergence rate of analysed countries. This fact can be explained by mismatch of education system with the labour market and poor PISA average scores in Reading, Mathematics and Science in 2018 in several CESEE countries especially Romania and Bulgaria. Possible explanation for insignificance of institution quality is that the quality worsened over time in several CESEE countries. Moreover, World Bank institution quality index is comprised of four indicators: government effectiveness, regulatory quality, rule of law and control of corruption. Most of the indicators worsened during and after "Migrant Crisis" especially in Hungary and some of them in other countries such as Lithuania, Poland, Romania and Slovak Republic. On the other hand, institutional quality has improved in Estonia and probably contributed to high level of convergence that Estonia achieved, but, generally, the aforementioned indicators of institution quality got worse. Innovations also proved to be an insignificant factor for convergence rate. This is explained by heterogeneity of innovation development in CESEE countries. According to World Intellectual Property Organization, the indicator of patent application is very low in most CESEE countries besides Slovenia and Poland. Also, as it was already pointed out, benefits from innovations are not automatic and demand the implementation of policies that support innovation. As the institutional quality in analysed countries is still low, the full effect of innovation transformation into economic growth is hindered.

To summarize, economic growth and convergence in CESEE economies was fuelled by increasing openness, international trade and FDI, and some CESEE economies managed to increase their global markets competitiveness. However, in some economies these high current account deficits persisted which implies external competitiveness issues. In countries with lower external competitiveness, convergence was slower. In most CESEE countries (Czech Republic, Slovakia, Hungary, Croatia, Romania, Bulgaria and Slovenia) most convergences occurred before financial crisis, while some countries (Estonia, Lithuania, Latvia and Poland) were converging even faster after the crisis. Economic growth in the first group of countries was mainly based on trade, capital accumulation and FDI and only partially on total factor productivity growth, while the contribution of the labour market characteristics was negligible or even negative. After the financial crisis, FDI declined resulting in slowdown in overall investment. Besides, most CESEE countries experienced emigration trends and unfavourable demographic development. On the other hand, economic growth of the second group of countries was, besides common factors, also supported by development of institutional quality and human capital, which improve the capacity of absorbing European Structural and Investment Funds which are of great 
importance for economic convergence. Therefore, due to the fundamental role of institutional quality and human capital in economic and, more importantly, social development, their improvement will be the key challenge for most of CESEE economies in the upcoming decade. Also, the transformation towards more technologically advanced and innovative economies will remain the prerequisite for all CESEE countries in order to reach sustainable convergence and avoid the middle-income trap. Finally, the assessment of their success will be visible in the long run.

\section{Conclusion}

This paper has analysed conditional convergence and the causes of different convergence rates among CESEE countries between 2002 and 2018. The importance of convergence stems as from the far-reaching implications of real income for economic well-being as well as from the importance of convergence for economic integration within the EU. The paper has identified stylized convergence facts and analysed the drivers of economic growth, i.e. the capital accumulation, FDI, trade openness, labour market characteristics and factors of total factor productivity growth in the context of CESEE countries.

Our paper has shown that CESEE countries in the analysed period converged and consequently reduced the gap in terms of GDP per capita. However, the rate of convergence varied across countries and periods. This suggested that the importance of some convergence rate factors changed over time and our panel data analysis confirmed this assumption. Namely, capital accumulation, trade openness and relation to Eurozone proved to be significant in the analysed period. Still, FDI, labour market, human capital, institutions and innovation did not prove to be significant, which is not in line with expectations and confirms significant changes in convergence patterns and differences between economies regarding convergence pace.

The results imply that most CESEE countries, on the one hand, experienced decline in FDI and negative migrations considering labour market and that, on the other hand, they failed in improving institutional quality and human capital as the prerequisites for development of innovation and business friendly environment. Basing economic growth on capital accumulation and FDI is not sustainable, whereas the development of institutional quality, human capital, innovation and labour market reforms (high labour market participation rate) are of crucial importance.

Challenges related to the declining share of the working age population and unfavourable demographic trend are expected to increase because of the accelerated aging of the population. These challenges can be mitigated by increased labour participation, especially among young people, women and the elderly. The mismatch between education system and labour market still exist in many CESEE economies and education reforms are required. Moreover, development of innovation and institutional quality will be the basis for increasing and maintaining convergence in future, and also for resisting the negative impacts of aging population and emigration trends. Finally, we can conclude that besides real and nominal convergence, some CESEE countries are facing challenges of institutional convergence, whereby institutional quality is eroding, what diminishes the capacity of these countries to use European Structural and Investment Funds which are considered as a catalyst for economic convergence.

\section{References}

[1] Acemoglu, D. and Robinson, J. (2010). The role of institutions in growth and development. Review of Economics and Institutions, 1(2), 1-33. doi: 10.5202/rei.v1i2.14

[2] Atoyan, R., Christiansen, L., Dizioli, A., Ebeke, C., Ilahi, N., Ilyina, A., Mehrez, G., Qu, H., Raei, F., Rhee, A. and Zakharova, D. (2016). Emigration and its economic impact on Eastern Europe. IMF Staff Discussion Note, 16(07), 1-48. 
https://www.imf .org/en/Publications/Staff-Discussion-Notes/Issues/2016/12/31/

Emigration-and-Its-Economic-Impact-on-Eastern-Europe-42896

[3] Baltagi, B. H. (2013). Econometric Analysis of Panel Data, 5th Edition. Chichester: Wiley.

[4] Barro, R. J. and Sala-i-Martin, X. (1992). Convergence. Journal of Political Economy, 100(2), 223-251. doi: /10.1086/261816

[5] Borsi, M. T. and Metiu, N. (2015). The evolution of economic convergence in the European Union. Empirical Economics, 48(2), 657-681. doi: 10.1007/s00181-014-0801-2

[6] Bubbico, R. L., Gattini, L., Gereben, Á., Kolev, A., Kollár, M. and Slacik, T. (2017). Wind of change: Investment in Central, Eastern and South Eastern Europe.

Research Report of the EIB Economics Department. https://www.eib.org/en/publications/ econ-report-wind-of-change-investment-in-cesee

[7] Colak, O. (2015). Convergence revisited: Case of EU and Eastern Europe. Regional Science Inquiry, 7(1), 69-81. http://www.rsijournal.eu/ARTICLES/June_2015/6.pdf

[8] Damijan, J., Kostevc, Č. and Rojec, M. (2013). FDI, structural change and productivity growth: Global supply chains at work in Central and Eastern European countries. IRMO Occasional Paper, 1, 1-29. https://www.irmo.hr/wp-content/uploads/2013/11/IRMO-OP-1_2013-sa-ISSN.pdf

[9] Dobrinsky, R. and Havlik, P. (2014). Economic convergence and structural change: The role of transition and EU accession. WIIW Research Report, 395, 1-31.

[10] Drukker, D. M. (2003). Testing for serial correlation in linear panel-data models. The Stata Journal: Promoting communications on statistics and Stata, 3(2), 168-177. doi: /10.1177/1536867x0300300206

[11] Dvoroková, K. (2014). Sigma versus Beta-convergence in EU28: Do they lead to different results, Proceedings of the Mathematical Methods in Finance and Business Administration, 88-94. http: //www . wseas.us/e-library/conferences/2014/Tenerife/ECONMATH/ECONMATH-13.pdf

[12] Fidrmuc, J., Martin, R. (2011). FDI, trade and growth in CESEE countries. Focus on European Economic Integration, Q1/11, 70-89.

https://www . oenb.at/en/Publications/Economics/Focus-on-European-Economic-Integration/ 2011/Focus-on-European-Economic-Integration-Q1-11.html

[13] Hausman, J. (1978). Specification tests in econometrics. Econometrica, 46(6), 1251-1271. doi: $10.2307 / 1913827$

[14] Grela, M., Majchrowska, A., Michałek, T., Mućk, J., Stažka-Gawrysiak, A., Tchorek, G. and Wagner, M. (2017). Is Central and Eastern Europe converging towards the EU-15? NBP Report.

[15] Jelnikar, E. and Murmayer, U. (2006). Convergence in Europe: Empirical analysis on two groups of countries of the European Union. Proceedings of the International Conference on Human and Economic Resources, 249-263.

[16] Kaufmann, D., Kraay, A. (2002). Growth without governance. Economía, 3(1), 169-229. doi: $10.1353 /$ eco.2002.0016

[17] Kulhánek, L. (2012). Real convergence in Central and Eastern European EU member states. MPRA Working Paper, 39822, 1-9. https://mpra.ub.uni-muenchen.de/39822/1/MPRA/_paper/ _39822.pdf

[18] Mankiw, N. G., Phelps, E. S. and Romer, P. M. (1995). The Growth of Nations. Brookings Papers on Economic Activity, 1, 275-326. doi: 10.2307/2534576

[19] Maradana, R. P., Pradhan, R. P., Dash, S., Gaurav, K., Jayakumar, M. and Chatterjee, D. (2017). Does innovation promote economic growth? Evidence from European countries. Journal of Innovation and Entrepreneurship, 6(1), 1-23. doi: 10.1186/s13731-016-0061-9

Oblath, G., Palocz, E., Popper, D. and Valentinyi, Á. (2015). Economic convergence and structural change in the new member states of the European Union. IEHAS Discussion Papers, 44, 1-79. http://econ.core.hu/file/download/mtdp/MTDP1544.pdf

[20] Pece, A. M., Simona. O. E. O. and Salisteanu, F. (2015). Innovation and economic growth: An empirical analysis for CEE countries. Procedia Economics and Finance, 26, 461-467. doi: 10.1016/s2212-5671(15)00874-6

[21] Rodríguez F. (2006). Openness and growth: What have we learned? UN Department of Economic and Social Affairs Working Papers, 51, 1-28. doi: 10.18356/c6dee82f-en

[22] Rodríguez, F., Rodrik. D. (1999). Trade Policy and Economic Growth: A Skeptic's Guide to the Cross-National Evidence. NBER Working Paper Series, 7081, 1-45. doi: 10.3386/w7081 
[23] Rodrik, D. (2000). Institutions for high-quality growth: What they are and how to acquire them. Studies in Comparative International Development, 35(3), 3-31. doi: 10.1007/bf02699764

[24] Siljak, D. and Nagy, S. G. (2019). Economic convergence between the Western Balkans and the new EU member states (EU-13). Romanian Journal of European Affairs, 19(1), 51-64. http://rjea. ier.gov.ro/wp-content/uploads/2019/06/RJEA_vol.19_no.1_June-2019-ARTICOL-4 .pdf

[25] Spence, M. and Leipziger, D. (2010). Implications for a post-crisis world. Globalization and Growth. doi: 10.1596/978-0-8213-8220-2

[26] Solow, R. M. (1956). A contribution to the theory of economic growth. The Quarterly Journal of Economics, 70(1), 65-94. doi: 10.2307/1884513

[27] Suri, T., Boozer, M. A., Ranis, G. and Stewart, F. (2011). Paths to success: The relationship between human development and economic growth. World Development, 39(4), 506-522. doi: 10.1016/j.worlddev.2010.08.020

[28] Škrabić Perić, B. (2019). Do the most frequently used dynamic panel data estimators have the best performance in a small sample? A Monte Carlo comparison. Croatian Operational Research Review, 10(1), 45-55. doi: 10.17535/crorr.2019.0005

[29] Vojinović, B., Acharya, S. and Próchniak, M. (2009). Convergence analysis among the ten European transition economies. Hitotsubashi Journal of Economics, 50(2), 123-141. https: //www.jstor.org/stable/43296221 